\title{
Redaktørens forord
}

Årets tredje nummer af Dansk Sociologi tilbyder to artikler, et essay og tre anmeldelser. I »McDonaldiseringen af dansk politi« tager Adam Thomas Diderichsen afsæt i den amerikanske sociolog George Ritzers diskussion af samfundets McDonaldisering. Diderichsen bringer Ritzers begreb i spil i en analyse af dansk politis udvikling i de senere år mod mere målstyring og effektivisering og indlejrer den i den bredere diskussion om New Public Management. Carsten Kronborg Baks artikel »Sundhedskompetencer som en sociokulturel ressource i sundhed « præsenterer og udfolder begrebet om sundhedskompetencer (health literacy) for et dansk sociologisk publikum. Kronborg Baks formål er især at vise, hvordan diskussionen af sundhedskompetencer kan kvalificeres gennem en inddragelse af Bourdieus begreber om »kapital «. I essayet "Studenteroprøret på sociologi. Fagkritik og pædagogisk fornyelse« tager Finn Hansson os med tilbage de intense år omkring 1968, hvor de studerendes kritik forandrede de danske universiteter, herunder også sociologien. Hansson viser samtidig, hvordan oprøret blev diskuteret og implementeret $\mathrm{i}$ de efterfølgende årtier. Nummeret rundes af med tre anmeldelser. Tidsskriftet udsender desuden et call for papers til et kommende temanummer om corona.

Thomas Olesen

Foto side 4: Rørelse. Foto: Karin Lorentzen 